\title{
DE MIGRANTE A INDUSTRIÁRIO: A RECONSTRUÇÃO DA VIDA NA CIDADE DE MANAUS
}

\author{
FROM MIGRANT TO INDUSTRIAL: THE RECONSTRUCTION OF LIFE IN THE CITY \\ OF MANAUS
}

\section{A. O. ANDRADE ${ }^{1, *}$}

1 Universidade Federal do Amazonas, ICSEZ - Instituto de Ciências Sociais, Educação e Zootecnia. Manaus/AM, Brasil

\author{
ART ICLE INFO \\ Article history: \\ Received 2018-07-02 \\ Accepted 2018-10-16 \\ Available online 2018-10-31 \\ *Autor correspondente: \\ E-mail: aldairandrade@yahoo.com.br
}

Palavras-chave: Migração interna-Amazonas. Trabalho migratório-Brasil. Manaus (AM). Indústrias.

Keywords: Internal migration-Amazonas. Migratory workBrazil. Manaus (AM). Industries.

RESUMO. Este trabalho abordou do processo de reconstrução da vida de migrantes amazonenses na cidade de Manaus, que aportaram à capital a partir da década de 1960, nela desempenharam ou desempenham atividades no Polo Industrial de Manaus (PIM). O trabalho teve como intenção, a partir das narrativas dos migrantes, situar a construção do projeto migratório, os dilemas que envolveram o ato de migrar, a chegada à capital, a inserção no mundo do trabalho, a construção de novos espaços de sociabilidade, dentre outras questões, as quais nos ajudaram a identificar se o projeto construído na origem se consolidou no destino. Nos debruçamos sobre uma pesquisa bibliográfica, matérias jornalísticas e os relatórios oficiais do poder público, e acentuadamente da pesquisa de campo. A coleta de campo foi realizada a partir de entrevistas semiestruturadas com trabalhadores migrantes que atuam ou atuaram no PIM, com base nos critérios previamente estabelecidos, no intuito de conhecer como era a vida na origem, o que determinou a decisão de migrar, como se deu o deslocamento, como foi o estabelecimento em Manaus, quais as principais dificuldades enfrentadas, como se tornaram industriários, como é a vida no espaço fabril e como eles construíram novas relações sociais. De modo geral podemos asseverar que o estudo evidenciou que nem todos construíram seus próprios projetos migratórios na origem, visto que eram crianças e adolescentes, que tiveram a decisão tomada por pais ou responsáveis. A presença de familiares e conhecidos no destino (capital) foi um elemento 
fundamental para subsidiar a decisão de migrar. Os migrantes se tornaram industriários somente após a chegada à Manaus, por isso, nesta pesquisa adotou-se o termo migrantes industriários. Ao comparar a vida na origem e no destino, inferimos que houve melhoria de vida, sendo os principais objetivos do projeto migratório, estudo, trabalho e moradia, foram alcançados por maioria significativa dos migrantes, muito embora os relatos não deixem de revelar a dureza da vida de um industriário, que tem a maior parte de seu tempo consumida pelo trabalho.

ABSTRACT. This research addresses the process of migrants $i$ life reconstruction in the city of Manaus who arrived in the capital from the 1960, when they developed activities in the Industrial Pole of Manaus (PIM). The intention of this work is, from the migrants' narratives, to place the construction of the migratory project, the dilemmas involved in the act of migrating, the arrival in the capital, their entering in the market place, the construction of new spaces of sociability, among other questions, which help us identify if the project in its origin was consolidated at the end. To achieve that, the literature we used also includes newspaper articles and official reports of public institutions, as well as field research. For data collection, we conducted semi-structured interviews with workers who worked at the PIM, based on previously established criteria, in order to know what life was like at the beginning, what determined their decisions to migrate, how the displacement took place, the way their establishment in Manaus occurred, which were the main difficulties they faced, how they became industry workers, what was life like in the factory space and how they built their new workplace relationships. The study showed that not all of them created their own migration projects, since they were children and teenagers who had the decision made by their parents or guardians. The presence of family members and acquaintances in the capital was a key element to support the decision to migrate. Migrants have become industrial workers only after their arrival in Manaus, therefore, this research adopts the term migrant industrial workers. Comparing life in the origin and destination, we can infer that there was an improvement in the migrantsi lives, and the main objectives of the migration project, which were the study, the work and the housing, were achieved by most of them, although the reports do not fail to reveal the hard life of an industrial worker, who has most of his/her time consumed by the job.

\section{Referência}

ANDRADE, Aldair Oliveira de. De migrante a industriário: a reconstrução da vida na cidade de Manaus. 2014. 363 p. Tese (doutorado) - Universidade Estadual de Campinas, Instituto de Filosofia e Ciências Humanas, Campinas, SP. Disponível em: <http://www.bibliotecadigital.unicamp.br/document/?code=000941466>. Acesso em: 2 abr. 2018. 